\title{
OBGANIZATIONAL DISTANCE AND USE OF COLLATERAL FOR BUSINESS LOANS
}

Gabriel Jimenez, Vicente salas - unas. and Jesus saumina.

Documentos de Trabajo. N. 0816 .

\section{baneodespaña}

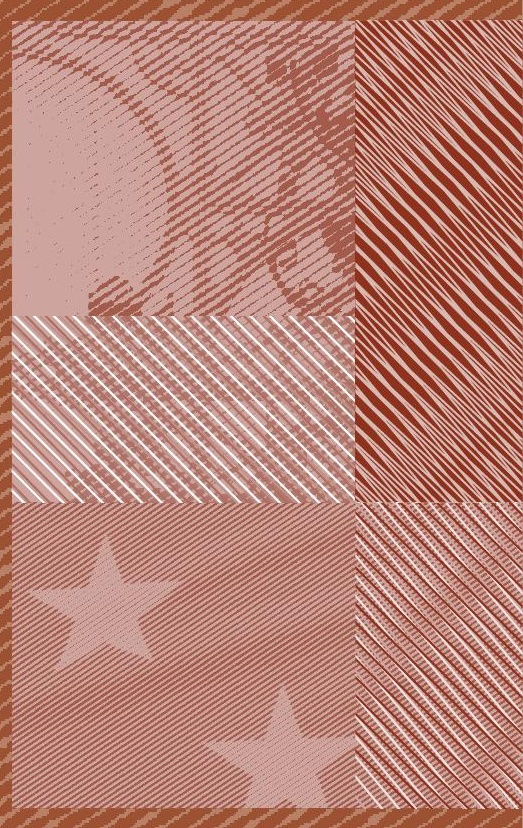


ORGANIZATIONAL DISTANCE AND USE OF COLLATERAL FOR BUSINESS LOANS 
ORGANIZATIONAL DISTANCE AND USE OF COLLATERAL FOR BUSINESS LOANS

Gabriel Jiménez

BANCO DE ESPAÑA

Vicente Salas-Fumás

UNIVERSIDAD DE ZARAGOZA Y BANCO DE ESPAÑA

Jesús Saurina ${ }^{(*)}$

BANCO DE ESPAÑA

${ }^{(*}$ ) This paper is the sole responsibility of its authors and the views presented here do not necessarily reflect those of Banco de España.

(*) Address for correspondence: Jesús Saurina, C/ Alcalá, 48, 28014 Madrid, Spain. Tlf: + 3491338 5080; e-mail: jsaurina@bde.es. 
The Working Paper Series seeks to disseminate original research in economics and finance. All papers have been anonymously refereed. By publishing these papers, the Banco de España aims to contribute to economic analysis and, in particular, to knowledge of the Spanish economy and its international environment.

The opinions and analyses in the Working Paper Series are the responsibility of the authors and, therefore, do not necessarily coincide with those of the Banco de España or the Eurosystem.

The Banco de España disseminates its main reports and most of its publications via the INTERNET at the following website: http://www.bde.es.

Reproduction for educational and non-commercial purposes is permitted provided that the source is acknowledged.

\section{(C) BANCO DE ESPAÑA, Madrid, 2008}

ISSN: 0213-2710 (print)

ISSN: 1579-8666 (on line)

Depósito legal: M. 40034-2008

Unidad de Publicaciones, Banco de España 


\begin{abstract}
This paper examines the effect of organizational distance (i.e. distance between the headquarters of the bank that grants a loan and the location of the borrower) on the use of collateral for business loans by Spanish banks on the basis of the recent lender-based theory of collateral [Inderst and Mueller (2007)]. We find that, for the average borrower, the use of collateral is higher for loans granted by local lenders than by distant ones. We also show that the difference in the likelihood of collateral in loans granted by local lenders, relative to distant lenders, is higher among older and larger firms and among firms with longer duration of the lender-borrower relationship, than, respectively, younger, smaller firms and shorter duration. We also find that banks use lending technologies that are different for near and for distant firms, in response to organizational diseconomies.
\end{abstract}

JEL: G21, L22

Keywords: bank lending technologies, distance, collateral, organizational diseconomies. 
The physical location of banks is relevant in determining the terms and availability of banking services. Customers' transportation costs produce spatial differentiation of banks' softening competition [Chiappori et al. (1995)]. Banks' costs of gathering and processing site-specific information about potential borrowers increase with distance [Almazan (2002); Petersen and Rajan (2002)] so distant banks will be less informed about local credit market conditions than banks closer to the borrowers. ${ }^{1}$ Previous research has documented an increase in distant bank lending to small business over time, especially in the US, and has examined its causes [Mester (1997); Petersen and Rajan (2002); DeYoung, Hunter and Udell (2004)], as well its consequences in terms of interest rates on loans [Petersen and Rajan (2002), Degryse and Ongena (2005); Agarwal and Hauswald (2007)] and of the credit quality of the loans granted [Carling and Lundberg (2002); DeYoung, Glennon and Nigro (2006)]. This paper examines the unexplored issue of how the firm-bank distance affects the use of collateral for loans, with Spanish data on individual bank loans. ${ }^{2}$

Why loans are collateralised (or not) has traditionally been explained as the result of informational advantages of borrowers over lenders; in these situations, the use of collateral attempts to offset the problems of adverse selection [Bester (1985); Chan and Kanatas (1985); Besanko and Thakor (1987a and b)] and/or of moral hazard [Chan and Thakor (1987); Boot, Thakor and Udell (1991)] caused by information asymmetry. On the other hand, Inderst and Mueller (2007) explain the use of collateral as a way to exploit the information advantage of local lenders, relative to distant ones, in evaluating the credit risk of a loan in situations where competition limits the interest rates that local banks can charge on the loan (positive reservation profit of the borrower). In old models, the use of collateral varies across loans as a function of the characteristics of borrowers ("borrower-based" theories), while in the more recent "lender-based" theory of Inderst and Mueller, the use of collateral varies with the characteristics of lenders, namely the relative informational advantage of local over distant lenders. We draw on the lender-based theory of collateral to formulate the empirical hypothesis on the effect of distance in the likelihood of the use of collateral in business loans.

Advances in credit scoring, and other transactional lending techniques, enlarge the relevant market around a branch and therefore, with fixed costs per branch, we expect to see an increase in the average distance from the branch to customers' locations, and a decrease in the equilibrium number of branches serving the whole territory. In Spain, however, banks expand geographically, opening branches country-wide, and the density of branches per capita remains stable over time. We also provide evidence that loans granted in a province by banks with no branches in that province have been - and continue to benegligible, while the distance between the location of the headquarters of the bank and the

1. A distinction is made between soft information, collected by the bank through repeated direct interactions with the firm it does business with, and hard information that is equally available to close and distant lenders. The use of soft versus hard data in lending decisions is more correlated with relational or transactional lending technologies, respectively [Boot (2000); Berger and Udell (2002)]. Dell'Ariccia and Márquez (2004) and Hauswald and Marquez (2006) explicitly model banking competition and interest rate determination, assuming that banks' information on borrowers decreases with distance.

2. The use of collateral is very common in loans to business firms [Berger and Udell (1995); Harhoff and Körting (1998); Degryse and van Cayseele (2000); Jiménez, Salas and Saurina (2006a)], and has micro- and macro-economic implications in terms of credit availability [Jiménez, Salas and Saurina (2006b)] and economic growth [Bernanke, Gertler and Gilchrist (1999)]. 
provinces where the loans are granted, increases in parallel to branch expansion. We have no direct evidence as to how the physical distance from firms to the banks they borrow from has evolved over time in Spain but, from other evidence available a relevant research question to ask is how the use of collateral in business loans is affected by the observed increase in organizational distance, namely that between the headquarters of the bank (top decision-making power) and the operating branches serving customers in local markets. ${ }^{3}$

We address this research question with a large data-base on individual loans to firms by Spanish banks in the period 1992 to 2002. The data come from the Credit Register of the Banco de España, which contains information on all loans of 6,000 euros or more granted by all Spanish banks, to firms of all sizes, anywhere in the country. The sample data used in the paper includes all loans to firms for which accounting data from the Commercial Register is available for the year before the loan was granted (almost half a million loans). Accounting ratios, together with size, and the past loan-defaulting history of the borrower (as reported in the Credit Register), are the kind of hard data that can be used by distant lenders to assess the credit quality of the borrower. For each loan, we know its size, maturity and if it is collateralised or not, but information on the interest rate is not available. The use of collateral is the dependent variable to be explained as a function of the firm-bank organizational distance, hard (accounting) data on the credit quality of the borrower, relational lending variables, characteristics of the loan and province, bank, industry and time control variables. Not knowing the interest rate of the loan should not be a major limitation in explaining the use of collateral, since the interest rate and the use of collateral are both jointly-determined, endogenous, variables, and each should be explained separately as a function of the relevant exogenous variables. Two limitations of the data are that we do not know the physical distances of the firm-branch and of the firm-nearest branch from a competing bank, and we have no information on loan applications that were refused by banks. Physical distances have been available only in studies that use data on loans granted by a single bank [Carling and Lundberg (2002); Degryse and Ongena (2005); Agarwal and Hauswald (2007)]. Our data includes loans granted by the population of banks, and we use an alternative proxy for information differences between local and distant banks. On the other hand, Agarwal and Hauswald (2007) find that controlling for sample-selection bias does not affect their main findings.

Banks can be physically closer to potential borrowers by opening branches in local markets. But whether physical proximity to the customer will reduce the informational advantage of local banks (those with headquarters and decision-making power physically close to the borrower) over organizationally-distant ones (those with headquarters and decision-making power a distance away from the local branch) is an open question. If the bank centralizes decision-making power to avoid agency and related costs of delegation, then information on the credit quality of the loan application will have to be communicated from the local branch to the bank headquarters. The quality of the centralized decisions will depend on the quality and information content of the data communicated, received and processed. Alternatively, the bank may decide to decentralize the decision on granting the loan, and its terms, to the branch manager, thus avoiding distortions in the communication process, but it then faces agency and related costs of delegation. The two

3. The organizational distance variable is used by Berger and De Young (2001) to measure the distance in miles between the parent and the affiliate in US multi-bank holding companies. They are interested in testing how control of parent over affiliated banks has evolved over time according to advances in new banking technologies. Alessandrini, Presbitero and Zazzaro (2006) refer to functional distance which includes spatial as well as cultural distance between the headquarters of the bank and the province where the bank has branches; they investigate if functional distance affects the credit constraints of firms. 
solutions imply organizational diseconomies [Stein (2002)] i.e., a loss in efficiency compared with what could be achieved if there were no information asymmetries and conflicts of interests.

Banks, like any complex organization, are affected by organizational diseconomies, and the evidence confirms that their internal decision-making and control processes are responsive to such factors. For example, Berger et al. (2005) find that lending transactions with small firms follow a different pattern if the lender is a small bank, than if it is a large bank: large banks tend to rely more on hard data and transactional lending, while small banks specialise in the use of soft data and relational lending. They explain the different lending practices between small and large banks as a consequence of organizational diseconomies, which force large banks to rely on hard, codified data for internal transmission of information. When organizational diseconomies are important, the organizational distance becomes the key supply-side factor affecting the terms of loans, independently of whether banks have branches in the local market or not. In testing the hypothesis from the lender-based theory of collateral, we use organizational distance as a proxy for information differences about local market conditions among competing banks.

We find that organizational distance is a relevant variable in explaining the use of collateral for business loans, in two ways. First, the likelihood of the use of collateral decreases with organizational distance, and the effects of the distance variable on such likelihood are independent of the experience of the bank in the province. Second, the effect of organizational distance on the likelihood of collateral, decreases when the accounting variables (hard data), which refer to the credit quality of the firm, are included as explanatory variables of the use of collateral. Therefore, the empirical evidence supports the notion that organizational diseconomies affect the lending decisions of banks, and shows that hard data and organizational distance are, somehow, substitutes in the collateral decision. These results are in line with those of Agarwal and Hauswald (2007), who find that firm-bank physical distance is no longer statistically significant in explaining the interest rate of the loan, after controlling for banks' soft proprietary information on the credit quality of the borrower. This is interpreted as evidence that firm-bank proximity is a source of local informational advantage for the bank. On the other hand, we find that distant lenders can offset their informational disadvantage when hard data is available to assess the credit quality of the borrower.

We also find that, controlling for the credit quality of the borrower, the effect of organizational distance on the use of collateral for loans differs as a function of observable characteristics of the firm, such as age and size: the likelihood of collateral increases with organizational proximity (the opposite to organizational distance) in loans granted to older and larger firms, while it decreases with proximity in loans granted to younger and smaller firms. This evidence is consistent with the lender-based theory of collateral, which predicts that local lenders are more likely to ask for collateral for loans granted with lower informational advantage, which is expected to be the case among larger and older firms, for whom more public information will be available.

Another finding of the paper is that the likelihood of the use of collateral decreases with concentration in the credit market, but it does so at a lower rate in loans granted to borrowers with longer-standing relationships with the lender. Competition is expected to be lower as the credit market becomes more concentrated. The lender-based theory of collateral predicts that local lenders will use collateral to collect rents from borrowers that have higher 
reservation profits, i. e. they obtain higher profits by getting the loan from a distant bank. In more concentrated (less competitive) markets, reservation profits are expected to be lower, and therefore less use of collateral is expected - a prediction corroborated by the empirical evidence. There are, however, other explanations of the use of collateral as a function of credit market competition, consistent with this evidence. The unique prediction from the lender-based theory of collateral is that the effect of higher reservation profit on the decision to use collateral is less, the higher the informational advantage of the local lender. Longer duration of the firm-bank relationship is expected to increase the informational advantage of the lender, so the estimated positive cross-effect of market concentration and duration variables on the likelihood of collateral supports the prediction from the lender-based theory of collateral.

Finally, we find no different time trend in the likelihood of collateral in loans granted by local versus organizationally distant lenders, controlling for the other explanatory variables of the collateral decision. This evidence suggests that advances in transactional lending technologies (credit-screening methodologies) over time, if any, do not seem to have altered the competitive conditions of the credit market for firms in Spain.

The paper contributes to the literature in two significant ways. First, it provides the first direct evidence on how organizational distance affects the use of collateral to secure bank loans to firms, which helps to explain why organizational diseconomies induce banks to specialize in different lending technologies for local and for distant borrowers. Second, the paper is the first to empirically test the predictions from the lender-based theory of collateral, the only one that explains the use of collateral solely as the result of informational advantages of local lenders, and the threat of distant lenders to challenge them, taking advantage of technological developments in transactional lending.

The rest of the paper is organized as follows. Section 2 contains the main hypothesis to be tested, drawn from the lender-based theory of collateral. Section 3 contains the data sources, the description of the observable variables and the formulation of the empirical model. Section 4 presents the results of the empirical analysis, including a description of the time evolution of organizational distance in lending in Spain. The discussion of main findings and conclusions closes the paper. 


\section{Firm-bank distance and use of collateral for loans}

The "lender-based" theory of collateral [Inderst and Mueller (2007)] explains why loans will be secured with collateral as a consequence of the heterogeneity of lenders in the same credit market. On the contrary, the "borrower-based" theory explains collateral as a function of information asymmetries between borrowers and lenders about the credit risk of the loan. In borrower-based explanations of collateral, all banks in the same relevant market face similar information asymmetries, while lender-based theories assume that there are two different banks, one local close to the borrower, and other distant from the borrower. The relevance of being a local or a distant bank is that the former has an informational advantage over the later.

Inderst and Mueller (2007) assume that the information advantage of the local lender is in the form of a more precise estimate of the success probabilities of the project to be financed. Borrowers are attracted by local lenders, but the outside option - the alternative of going to the distant lender- gives borrowers a reservation profit. This profit limits the interest the local lender can charge on the loan to exploit any informational advantage. Inderst and Mueller (2007) show that by asking for collateral, the local lender finds an effective and efficient way to overcome the limit on the interest rate, and still take advantage of any superior information. Collateral is of no use in lending by distant lenders, so the theory predicts that the use of collateral will be limited to loans granted by local lenders.

Transportation costs limit the relevant market for banking services to a relatively small radius around a particular bank branch. To increase their size, banks have to open branches in distant markets and by doing so they gain proximity to the potential customer. Branch managers of distant banks will collect information about the local credit market and, after some time, they will have the same information about the characteristics of the firms, and the projects in which they invest, as managers of local banks. Local and distant banks will face effectively different operating conditions when the local branch manager is an imperfect substitute for the top manager of the bank.

Organization diseconomies can cause such imperfections, resulting from the expected increase in management costs per unit of output, as the size and/or complexity of the organization increases. Management costs are those resulting from the coordination and motivation of people in organizations under information asymmetries, and from conflicts of interest between general management and the operating units of the organization. Communication costs create loss of control and distorted information transmission in hierarchical organizations [Williamson (1967); Harris and Raviv (2005)]. Delegation of decision power to lower level units reduces communication costs, but is likely to increase delegation and agency (motivation) costs if lower level units pursue their own objectives [Holmstrom (1979); Aghion and Tirole (1997)].

As banks expand geographically, by opening branches/subsidiaries in remote markets, they become larger and more complex. The empirical evidence shows that their operating efficiency is inversely related to the average distance from headquarters to operating units [Berger and DeYoung (2001 and 2006)]. Senior management of the bank will try to minimize such inefficiencies, and will take action to respond to the distorted incentives of branch managers in transmitting private information to the bank headquarters, 
especially when information is soft and non-codified [Stein (2002); Brickley, Linck and Smith (2003)]. The empirical evidence also shows that the decision-making power of local branch managers is often restricted [Udell (1989)] and communication with headquarters is limited to that which cannot be easily distorted [Berger et al. (2005)]. Under these circumstances, branch managers will not be motivated to invest in soft information, which will not be used because they do not have the decision-making power to grant the loan, or because the information cannot be effectively communicated to the central loan officer. On the other hand, bank owners can create powerful incentives for organizationally distant branch managers to collect hard data, which can be internally communicated at low cost, by committing to funding the loans that originated such data [Stein (2002)]. ${ }^{4}$

Organizational diseconomies will then favor the use of hard data, and more formal communication, between branch managers who collect the relevant information on the loan application, and the distant officers who will make the final decision. As organizational distance increases, it is more likely that the loan will be processed using transactional lending technologies, which in turn implies that the loan is granted to safe and highly transparent borrowers, i.e. those borrowers for whom the loan is less likely to be collateralized [Berger and Udell (2002); Berger (2006)]. On the other hand, if organizational diseconomies are insignificant, then distant lenders with branches in local markets will learn by experience the characteristics of borrowers in their respective markets. As the experience of the distant bank in the local market increases, organizational distance will be less and less relevant in explaining the use of collateral for loans, since local and distant banks will progressively decide loan applications with the same information. Thus, the following hypotheses, if not rejected, will provide preliminary evidence in support of the lender-based theory of collateral $(\mathrm{H} 1 . \mathrm{a})$ and will validate the relevance of organizational distance as a proxy of information differences across banks (H1.b and H1.c).

H1. a) For given characteristics of the borrower, the likelihood of the use of collateral in bank loans decreases with organizational distance.

b) Organizational distance makes decisions on the use of collateral more dependent on hard and transparent data about the characteristics of the borrower.

c) The effect of organizational distance on the likelihood of collateral is the same for any level of experience of the bank in the local market.

\subsection{Distance, use of collateral and characteristics of firms}

Comparative static analysis from the main result of the lender-based theory of collateral provides further empirically testable predictions. Inderst and Mueller (2007) show that, if the theory is correct, one will observe a higher likelihood of collateral for loans to borrowers with ex ante credit risk than for loans to borrowers with low credit risk. They also show that the proportion of loans with ex post default will be higher among loans with collateral than among loans with no collateral. Jiménez, Salas and Saurina (2006) provide empirical evidence that supports this first prediction, and Jiménez and Saurina (2004) confirm that collateralized loans are ex post riskier than non-collateralized loans. However, the two empirical evidences are also consistent with borrower-based theories of collateral, assuming problems of adverse

4. Agarwal and Hauswald (2007) report that, in the bank they get the data from, credit decisions reside with branches, i.e. their credit decisions are highly decentralized. It is expected that banks will differ in their decentralization policies. 
selection and moral hazard in the borrower-lender relationship [Boot, Thakor and Udell (1991)]. ${ }^{5}$

The impossibility of separating predictions on the use of collateral from lender- and borrower-based theories of collateral occurs with other observable variables, such as the duration of the firm-bank relationship, and credit market concentration. Longer duration of the firm-bank relationship will implies higher informational advantage for the bank that grants the loan, and the lender-based theory predicts a lower likelihood of collateral in longer than in shorter relationships. But the duration of the relationship also supports mutual trust, and attenuates the problems of moral hazard originating from information asymmetry [Boot and Thakor (1994)]. ${ }^{6}$ In more concentrated credit markets, the reservation profit of the borrower will be lower, since competition is less intense. Therefore, from the lender-based theory, the use of collateral is less likely in more concentrated credit markets. The prediction is supported by existing empirical evidence [Jiménez, Salas and Saurina (2006a)], but again, there are alternative explanations from borrower- based theories.

The unique predictions from the lender-based theory of collateral are those from Inderst and Mueller's (2006) propositions 5 and 6, which imply a different effect of organizational distance (information advantage of local lenders) and credit market competition (reservation profit of the borrower) on the likelihood of the use of collateral, depending on the observable characteristics of the borrower.

The informational advantage of the local lender will be higher when lending to more opaque borrowers, since organizationally distant banks do not have reliable hard data (public information) for those borrowers to evaluate their credit risk. If organizationally distant banks can collect hard data for older and larger firms, but not for opaque, younger and smaller firms, then the informational advantage of the local lender will occur mostly among younger and smaller firms. The lender-based theory of collateral will predict that the likelihood of collateral for loans granted by local lenders will be higher than the likelihood of collateral for loans granted by distant lenders, within the groups of borrowers where the informational advantage of the former is lower, i.e., when lending to older and larger firms.

The duration of the borrower-lender relationship is expected to increase the private information on the borrower collected by the lender. But the same duration is expected to translate into higher informational advantage for loans granted by local lenders than for loans granted by distant ones, because the lender-borrower relationship produces private and soft information that flows — with difficulty — through long communication channels. Age and size of the firm imply more public knowledge, and hence more uniform information, for the local as well as the distant lenders who do business with them. Duration, on the other hand, is expected to be positively correlated with more private information, which can be valuable for local banks but not so much so for distant banks (assuming organizational diseconomies).

5. The literature distinguishes between predictions on collateral from credit risk observed by the lenders [Leeth and Scott (1989); Berger and Udell (1990 and 1995); Jiménez, Salas and Saurina (2006a)] and predictions under information asymmetry. These can either respond to unobserved characteristics of the borrower at the time of the loan [adverse selection; Bester (1985); Chan and Kanatas (1985); Besanko and Thakor (1987a and b)], or to unobserved effort [moral hazard, Chan and Thakor (1987); Boot and Thakor (1994)] or to unobserved characteristics and effort [Boot, Thakor and Udell (1991)]. If information asymmetry is reduced to that which causes adverse selection problems, the prediction is that the use of collateral will be positively associated with the credit quality of the borrower, since use of collateral is a signalling device.

6. Lenders could use their informational advantage to delay borrowers and ask for higher interest rates, and for more use of collateral in loans, compared to those with no information advantage [Sharpe (1990); Rajan (1992)]. In this case, longer borrower-lender relationships imply a higher likelihood of the use of collateral in loans. 
For this reason, a longer duration of the borrower-lender relationship is expected to decrease the likelihood of collateral for loans granted by both local and by distant lenders, but more intensively for the former that for the latter.

Proposition 6 of Inderst and Mueller (2007) establishes a different effect of reservation profits of the borrower on the likelihood of collateral for each level of informational advantage of the local lender: The difference in the likelihood of using collateral for a loan with higher reservation profits of the borrower, compared with that for a loan with lower reservation profits, will decrease with the informational advantage of the local lender. If duration of the borrower-lender relationship is a measure of private information the borrower has about the lender, then Proposition 6 of Inderst and Mueller says that the negative effect of market concentration (less competition) on the likelihood of collateral should be moderated by the duration of the borrower-lender relationship.

The predictions from propositions 5 and 6 are summarized in the following hypothesis.

H2. a) As organizational proximity of the bank-firm increases, the likelihood of the use of collateral is expected to increase for loans to older and/or larger firms.

b) Longer duration of the lender-borrower relationship is expected to lower the likelihood of collateral in loans granted by all lenders but more intensively in loans granted by local lenders than in loans granted by distant ones.

c) The likelihood of the use of collateral decreases with credit market concentration, but the rate of decrease is lower as the duration of the borrower-lender relationship increases. 
The empirical part of the paper combines two data sets, the Credit Register database of Banco de España (CIR) and the Commercial Register (CR). The CIR provides information on all new loans, above a minimum threshold of 6,000 euros, granted to firms by any Spanish bank. Our sample period runs from 1992 to 2002. For each loan, information is available about type of instrument, currency, collateral, amount, maturity, identity of the borrower, industry, region, identity of the lender, and if the loan is in default at the end of the year or not. ${ }^{7}$ However, no information is available on whether collateral is internal or external, nor on the interest rate, nor on the purpose of the loan. Each loan decision is matched with additional characteristics of the borrower; mainly those obtained using the accounting data that the firm reports to the $\mathrm{CR}$, including age of the firm and its industry. ${ }^{8}$

We know the province of the borrower, and the province where the headquarters of the bank is located. The variable organizational distance, DISTANCE, is calculated as the physical distance in $\mathrm{Km}$ between the location of the headquarters of the bank and the capital of the province where the firm is located. The inverse of distance, 1/DISTANCE, will measure bank-firm organizational proximity. Loans granted in the province where the bank has its headquarters are assigned an organizational distance equal to zero, i.e. they are considered to be loans granted by local lenders. The bank office where the loan is processed is not known, and the physical distance between the branch and the location of the borrower is not available. The experience of the bank in the province is measured by the variable SHARE, equal to the market share of the bank in the stock of business loans in the province at the end of the year.

There are 50 provinces in Spain, and this is the lowest level of geographic market for which desegregated data is available. Credit market concentration is measured by the Herfindahl index, HERFINDAHLm,t, equal to the sum of squared market shares of business loans granted by each bank in the province $m$, at the end of the year $t{ }^{9}$

From the CIR data we group borrowers into three credit risk categories: those who have a loan in default at the time they receive a new loan, those who do not have a loan in default at the time they receive a new one, but default the following year, and the remaining borrowers. Borrowers in the first group are identified by the dummy variable DEFAULT $\mathrm{t}_{\mathrm{t}-1}$, which takes the value of 1 if the borrower receiving the loan has any other loan in default, and 0 otherwise. Borrowers who default on a loan in $t+1$, not having defaults in $t-1$, are identified by the dummy variable DEFAUL $T_{t+1}$, which takes the value of 1 if the firm defaults (any loan) in $\mathrm{t}+1$ but did not have a default in $\mathrm{t}-1$, and 0 otherwise. The remaining borrowers include those who do not default in the year prior to, and in the year after, the loan is granted. Banks can consult the CIR to learn the credit situation of the borrower at the time the new loan is applied for. Therefore DEFAULT $\mathrm{T}_{\mathrm{t}-1}=1$ includes all borrowers of observed low credit

7. All banks have access to the total exposure of the borrower in the Spanish banking system at the time the loan is granted. They also know if the firm is in default on any of its existing loans. However, the CIR does not supply historical data on the borrower's previous defaults.

8. Commercial Register data is collected and sold by Informa, the Spanish division of Bureau Van Dyck.

9. Jiménez, Salas and Saurina (2006b) provide evidence of a positive association between the Herfindahl index in the representative province of banks and the Lerner index, a direct measure of the market power of banks. They also compare the concentration measures in Spanish provincial markets with those in more local markets, such as SMA used in US studies [as in Petersen and Rajan (1995), for instance]. 
quality. The other variable, DEFAULT $T_{t+1}$, is an indication of ex post credit quality of the borrower, in the sense that those borrowers with DEFAUL $T_{t+1}=1$ are borrowers who reveal ex post as of low credit quality.

Other observable characteristics of the borrower include size, age and accounting-based performance measures. Size of the firm is measured by total ASSETS at the end of year. Accounting statements provide measures of profitability, solvency and liquidity (ACCOUNTING VARIABLES). Profitability is measured by ROA = EBIT/ASSETS. The solvency and liquidity variables are: equity to assets ratio, EQUITY/ASSETS; coverage of interest expenses by earnings before interests and taxes, INTEREST INCOME/EBIT; debt maturity, SHORT TERM DEBT/TOTAL DEBT; the inverse of the current ratio, SHORT TERM DEBT/CURRENT ASSETS, and the liquidity ratio, CASH/TOTAL ASSETS. The variables size, equity finance, return on investment and liquidity are positively associated with the credit quality of the borrower; for the remaining variables, we expect a negative correlation to credit quality.

Controlling for ex ante risk (using accounting data), the evidence of a higher likelihood of collateral for borrowers with DEFAULT $T_{t+1}=1$, than for borrowers with DEFAULT $T_{t+1}=0$, supports the predictions on use of collateral and credit risk from the lender-based theory of collateral, and from the borrower-based theory when information asymmetry derives from problems of moral hazard. However, when information asymmetry creates problems of adverse selection, and collateral is used to signal high credit quality, then the likelihood of the use of collateral is expected to be higher for borrowers who do not default in $t+1$, i.e. in higher quality borrowers (see note 4).

AGE of the borrower is the number of years since the firm was created. The intensity of relational lending will be measured by the number of years since the lender granted the first loan to the borrower, DURATION. We use NUMBER OF LENDERS, the number of banks the borrower has loans with at the time the loan is granted, as a control variable, since duration of a given borrower-lender relationship is expected to be different across firms of the same age but who do business with more or fewer banks. We include age of the firm as a proxy for public information about the credit quality of the borrower, and duration as a proxy for private information.

Control variables include also SIZE of the loan, the amount of money lent in thousands of euros; SHORT TERM LOAN, a dummy variable that takes the value of 1 if the loan is of a maturity between 1 to 3 years, and 0 otherwise. ${ }^{10}$ We also control for fixed effects, including BANK, PROVINCE, INDUSTRY and TIME, among the explanatory variables of the collateral decision. There are 50 province dummy variables, each taking the value of 1 if the loan is granted to a firm located in the respective province, and 0 otherwise. Firms are grouped into 11 industries and the time dummy variables expand from December 1992 to December 2002. The sample data includes around 200 banks, both commercial and savings banks (credit cooperatives are excluded because of incomplete data).

10. Loans with maturity of less than 1 year are excluded, since we do not know if they are new loans or rollovers of existing loans. 
The full empirical model to be estimated is formulated as follows:

$\operatorname{Pr}\left(\right.$ COLLATERAL $\left._{j k t}=1\right)=F\left(\beta_{0}+\beta_{1} \log \left(1+\right.\right.$ DISTANCE $\left._{k t}\right)+\beta_{2} \operatorname{SHARE}_{k t-1}+$ $\beta_{3} \log \left(1+\right.$ DISTANCE $\left._{k t}\right)$ SHARE $_{k t-1}+\beta_{4}$ HERFINDAHL $_{t k}+\beta_{5} \log \left(1+\operatorname{DURATION}_{k t-1}\right)+$ $\beta_{6} \log \left(1+A G E_{k t-1}\right)+\beta_{7} D_{E F A U L T}{ }_{k t-1}+\beta_{8}$ DEFAULT $_{k t+1}+\beta_{9} \log \left(\operatorname{ASSETS}_{k t-1}\right)+$ $\beta_{10}$ ACCOUNTING PERFORMANCE MEASURES $_{k t-1}+$ CONTROL VARIABLES $_{k t}+$ $\beta_{11} \log \left(1+A G E_{k t-1}\right) \log \left(1+\operatorname{DISTANCE}_{k t}\right)+\beta_{12} \log \left(1+\operatorname{DURATION}_{k t-1}\right) \log \left(1+\operatorname{DISTANCE}_{k t}\right)+$ $\beta_{13} \log \left(1+\operatorname{ASSETS}_{k t-1}\right) \log \left(1+\operatorname{DISTANCE}_{k t}\right)+\beta_{14}\left(1+\operatorname{DURATION}_{k t-1}\right)$ HERFINDAHL $\left.{ }_{t k}\right)$

where $F(x)=1 / 1+\exp (-\beta x)$ is the Logistic distribution function. Index $j$ indicates loan, $k$ indicates firm and $t$ indicates time period. The dependent variable COLLATERAL $j$ ikt is a dummy variable that takes the value of 1 if loan $j$, granted to firm $k$ in period $t$, is collateralized and 0 otherwise. The explanatory variables that are likely to have decreasing marginal effects on the likelihood of collateral are introduced in the model in log form: ASSETS, AGE, DISTANCE, DURATION and SIZE OF THE LOAN. ${ }^{11}$ The model is first estimated excluding the cross effects variables, except Ln DISTANCE x SHARE. This basic model will be used to test $\mathrm{H} 1$ and to verify if the predictions on determinants of collateral from the borrower, and from the lender-based theories of collateral, are supported by our data. The predicted signs for the estimated coefficients in the basic model are: $\beta_{1}<0, \beta_{2}=\beta_{3}=0$ (from H1.a and H1.c). From $\mathrm{H} 1 . \mathrm{b}$ the absolute value of estimated $\beta_{1}$ is expected to decrease when age, size and accounting variables are added as explanatory variables. Other expected results are: $\beta_{4}<0$ (less competition), $\beta_{5}>0$ (reputation and information advantage of local lender), $\beta_{6}$ ? (positive from borrower-based and non- positive from lender-based), $\beta_{7}>0, \quad \beta_{8}>0 \quad \beta_{9}<0, \quad \beta_{10}<0$ (credit risk).

The second block of estimations will include the cross effects, one at a time, for the purpose of testing $\mathrm{H} 2$. The predicted signs for the estimated coefficients are $\beta_{11<0}, \beta_{13}<0$ (H2.a), $\beta_{12}>0$ (H2.b), $\beta_{14}>0$ (H2.c).

11. For AGE, DISTANCE and DURATION we add 1 before taking logs because these variables can take the value of zero. 


\subsection{Summary statistics}

Statistics on the variables that provide information about the situation of distant lending in Spain, from 1992 to 2004, are presented in Table I. For commercial banks, savings banks and credit cooperatives, we show the proportion of the volume of loans granted by banks with no branches in the province where the borrower is located; the average organizational distance (assuming that distance is zero if a loan is granted in the province where the bank headquarters is located), and the proportion of bank branches in provinces outside the province where the headquarters of the bank is located.

For all banks and years, the proportion of loans granted by banks with no branches in the province is very small. While this ratio is stable over time for commercial banks (around $5 \%$ ) and credit cooperatives (9\%), saving banks show a decline of around $4 \%$ to $8 \%$. These percentages can well be explained by the cross-border relationships between neighboring provinces. Thus, to have a branch in a market is still very important in Spain, in order to reach business customers. On the other hand, organizational distance has been steadily increasing over time for all ownership forms, but especially among savings banks, with average distance of $237 \mathrm{Km}$ in 1992 and $309.5 \mathrm{~km}$ in 2004, and among credit cooperatives, where distance doubles in the time period, from $72 \mathrm{Km}$ in 1992 to $146 \mathrm{Km}$ in 2004. Finally, the last three columns of Table I provide evidence of the geographical expansion of branches, mainly by savings banks and cooperatives. In 1992 commercial banks, saving banks and cooperatives had $77.2 \%, 39.2 \%$, and $11.7 \%$ of their branches distant from their headquarters (i.e. in a different province from that where the headquarters were located), respectively. In 2004, the proportions were $82.9 \%, 55.1 \%$ and $34.7 \%$, respectively.

Table II provides additional descriptive information on the characteristics of borrowers (non-financial firms of all ages) and the loans contained in the database to be used in the estimation of the model..$^{12}$ As shown, $31 \%$ of all loans with maturity longer than one year granted to business firms have collateral, a number in line with data from other countries [Berger and Udell (1990); Harhof and Körting (1998)]. Average organizational distance is $354 \mathrm{Km}$ with a maximum of $2,684 \mathrm{Km}$ and a minimum of $0 ; 30 \%$ of all loans are granted by local banks.

The average HERFINDAHL index across provinces and years is 7.15 , which implies an equivalent to around 14 banks of equal size in the province. ${ }^{13}$ Market concentration is comparatively lower than concentration values in US studies. For example, Black and Strahan (2002) report average deposit Herfindahl index of 19.1 across MSAs in the USA (standard deviation of 6.7). The reason is that the province, our relevance market by assumption, is a larger territory than an MSA. In around $2 \%$ of the loans, borrowers had a loan in default at the time of taking a new one, while in $3 \%$ of the loans, borrowers with no defaulted loans at the time they were granted a new one, default one or more of the loans

12. The accounting variables have been windsorized, setting the observations above (below) the $95^{\text {th }}\left(5^{\text {th }}\right)$ percentile at the value of the $95^{\text {th }}\left(5^{\text {th }}\right)$ percentile to eliminate extreme values that can distort the results. AGE and the NUMBER OF LENDERS have been windsorized in the same way, but only above their $95^{\text {th }}$ percentile.

13. Average concentration in provincial markets is rather low, and has been relatively stable over time despite intense merger activity. Low concentration and mergers have been compatible, thanks to the geographical expansion of existing banks opening branches across the country, as documented in Table I. 
in the following year. Since the data sample contains almost 500,000 loans, the sample sizes of loans with DEFAULT $T_{t-1}=1$, and with DEFAULT $T_{t+1}=1$, are around 9,000 and 13,500 observations, respectively. The average age of firms in the sample is 10.7 years, and the average size in terms of total assets is 3.05 million euros. The range of age and size is quite wide, so smaller and younger firms are well represented in the sample. ${ }^{14}$ The summary statistics of the accounting variables indicate that the economic and financial situation of the firms in the sample is quite diverse. The average length of the relationship between the borrower and the lender in the sample is 4.22 years, although dispersion in duration is also very high. The average size of the loan represents around $13 \%$ of the average assets of the firms in the sample, with high dispersion of values across firms. $43 \%$ of the loans in the sample are short-term, with a maturity of 1 to 3 years, and the rest are long-term.

\subsection{Collateral and organizational distance}

Table III presents the results of estimating the basic model that includes a test of hypothesis $\mathrm{H} 1$ on the relevance of organizational distance for the terms of the loans. Model 1 includes Ln DISTANCE, SHARE and Ln DISTANCE x SHARE as the only explanatory variables (together with control variables). Models 2 and 3 also include characteristics of the loan size and maturity, and characteristics of the borrowers, with variables such as DEFAULT $T_{\mathrm{t}-1}$, AGE, ACCOUNTING VARIABLES, DURATION and DEFAULT $T_{t+1}$.

The estimated coefficient on Ln DISTANCE is negative and statistically significant in all regressions (H1.a). In Model 1, when borrower and bank-borrower characteristics are excluded from the explanatory variables, the likelihood of collateral in a loan granted in the province where the bank has its headquarters, Ln DISTANCE $=0$, is $6.8 \%$ higher than the likelihood of collateral in a loan with organizational distance equal to the sample mean of $354 \mathrm{Km}$ (setting all other variables at their sample means). Moreover, as distance increases by $1 \%$, the probability that the loan will be collateralized decreases by $1.1 \%$. Therefore, organizational distance has economic relevance in addition to statistical relevance. Also, in Model 1, the coefficients of the SHARE and of SHARE x Ln DISTANCE are not significantly different from zero $(\mathrm{H} 1 . \mathrm{c})$. If the market share of loans in the province is a measure of knowledge of local market conditions by the bank, the evidence suggests that this knowledge does not affect the decision on collateral. The conjecture posed by the paper, to explain this result, is that organizational diseconomies prevent local information, collected in the local branches, being used by the central loan office of the bank.

Model 2 shows that, when public knowledge on borrowers' characteristics (size, age, accounting ratios, DEFAULT $T_{\mathrm{t}-1}$ ) is added as explanatory of the use of collateral for business loans, the estimated coefficient of Ln DISTANCE, in absolute value, is one-half, and significantly lower than that estimated in Model 1. This result is consistent with the hypothesis that organizational distance relies primarily on hard data for loan granting decisions, and for determining the terms of the loan, i.e., if the loan is secured with collateral or not (H1.b). The addition of further borrower characteristics as explanatory variables, those that are closely related to soft data (DEFAULT $T_{t+1}$ and DURATION), lowers further the estimated coefficient of the distance variable (Model 3). However, the new estimated coefficient in Model 3, for DISTANCE, is not statistically different from that of Model 2.

\footnotetext{
14. These numbers are in line with those used in other studies, such as Harhoff and Körting (1998) for Germany, and Petersen and Rajan (1995) and Berger and Udell (1995) for the US, although the average size of the firm in our sample is larger since the analysis here is not limited to small firms.
} 
Overall, hypothesis $\mathrm{H} 1$ is not rejected by the data. The finding in Table III, that the likelihood of collateral for loans increases as bank-firm organizational proximity increases (the inverse of distance), is consistent with the argument of Inderst and Mueller (2007), that collateral is useful to local lenders as a way to profit from their informational advantage about the true risk of the project to be financed. The fact that organizational distance loses statistical and economic significance, when the observable characteristics of the firm are included as explanatory variables, indicates that distant banks rely on hard data in their lending decisions. We find that distant banks lend to borrowers of observed high credit quality, and thus the likelihood of collateral for loans granted by distant lenders is lower than for loans granted by local lenders.

As a robustness analysis, we explicitly examine if the characteristics of borrowers from distant banks differ from those who borrow from local banks. To do so, we compare the likelihood of collateral for a local lender, DISTANCE=0, versus a distant lender, DISTANCE $>0$, for those loans where the borrower had no previous relations with the current lender, DURATION=0. The estimation, not reported, shows that the first loan from local lenders tends to be granted to smaller and younger borrowers, compared with the size and age of borrowers who begin the relationship with distant lenders (the observed credit quality, in terms of accounting variables, is the same in both groups of lenders). Furthermore, the borrower who begins the relationship with a local lender tends to have prior relations with a significantly lower number of banks than the borrower who begins a relationship with a distant lender. This corroborates the fact that borrowers who begin a relationship with a distant lender are, in fact, more informational transparent, and have higher bargaining power, than those who begin the relationship with a local lender.

\subsection{Other factors explaining the use of collateral}

Table III provides information on the determinants of the use of collateral, additional to those having to do with organizational distance, which can be reconciled with both lender- and borrower-based theories of collateral. The most complete estimation, Model 3, shows positive estimated coefficients for the variables DEFAULT $T_{t-1}$, and DEFAULT $T_{t+1}$; lower performance, in terms of solvency, liquidity and profitability of the borrower, also implies a higher likelihood of collateral. Further, the likelihood of collateral decreases with the size of the borrower (i.e. a negative coefficient for the variable Ln ASSETS is expected). Therefore, the prediction from the two theories, that the use of collateral is expected to be higher in riskier loans, is confirmed by the data.

The marginal analysis confirms the economic relevance of these findings. To be in the group of borrowers with a loan in default at the time of getting a new one, DEFAUL $T_{t-1}=1$, increases the likelihood of collateral for the new loan by $35.9 \%$, compared with the likelihood among borrowers who did not default on a loan the previous year. Those borrowers with no defaulted loans at the time of asking for the new loan, who default the subsequent year, DEFAULT $T_{t+1}=1$, increase the likelihood of collateral for the new loan by $17.2 \%$, compared with the likelihood of collateral for loans to those who do not default in $t+1$. A joint, one standard deviation change over the mean of the performance variables, in the direction of lower performance and more risk, increases the likelihood of pledging collateral for a loan by $38.1 \% .^{15}$

15. We have estimated the coefficient of DEFAULT $T_{t+1}$ with and without accounting variables and the results are practically identical in both cases. Thus, the evidence indicates that the variable DEFAULT $T_{t+1}$ tells us about the collateral decision with data not contained in previous year accounting variables. The simple correlations of DEFAULT $T_{t+1}$ with all the 
Another result of Table III, supported by both theories of collateral, is the negative association between likelihood of collateral and market concentration, the estimated negative coefficient of HERFINDAHL. That is to say, collateral is more likely in a more competitive credit market, assuming that competition is inversely related to market concentration. ${ }^{16}$

The AGE of the borrower has an estimated coefficient with negative sign in the model where DURATION is excluded (Model 2), and positive in the model with DURATION as an explanatory variable (Model 3). The estimated coefficient of DURATION is negative. The simple correlation between AGE and DURATION is 0.40 , so that when DURATION is excluded from the model, AGE captures part of the effect of the former in the decision on the use of collateral. The evidence that longer duration lowers the likelihood of the use of collateral is consistent with borrower- and lender-based theories of collateral, and consistent with findings from other empirical research [Berger and Udell (1995); Harhof and Körting (1998)]. The existing evidence of the use of collateral and age of the firm is less clear; controlling for duration, age tends to be non-significant on the collateral decision [Berger and Udell (1995); Harhof and Körting (1998)].

The evidence from Table III, that bank loans to older firms are more likely to be collateralized, controlling for duration, cannot be explained by borrower-based theories of collateral. In fact, Berger and Udell (1995) predict a negative sign for the coefficient of age: as time goes on, there are more opportunities to separate firms into good or bad credit quality firms. The evidence, however, can be explained from the lender-based theory of collateral if the informational advantages of local versus distant lenders decreases as firms get older, i.e. if public knowledge on the credit quality of the firm increases with age of the firm.

The basic model on the determinants of collateral (Model 3) also shows that the likelihood of collateral in business loans is highly dependent on loan characteristics such as the volume of the loan and its maturity: larger volume and longer maturity of loans imply a higher likelihood of collateral.

\subsection{The cross effect of distance and characteristics of firms in the use of collateral}

To test the predictions specific to the lender-based theory of collateral, $\mathrm{H} 2$, the empirical model must incorporate the cross effect variables, as shown in Table IV (SHARE was excluded, since it appeared to be statistically non-significant). The first estimation, Model 1 , adds the cross effect of age and distance. In the new estimation, Ln DISTANCE has a positive estimated coefficient, while the coefficient of the cross effect variable is negative.

other explanatory variables, including accounting ratios, gives correlation values always lower than $4 \%$. We have estimated the model including DEFAULT $T_{t+1} \times \operatorname{Ln}$ AGE, and DEFAULT $T_{t+1} \times \operatorname{Ln}$ ASSETS, as additional explanatory variables (one at a time) to evaluate if information in DEFAULT $T_{t+1}$ is affected by the age and size of the firm. In both cases, the coefficient of DEFAULT $T_{t+1}$ now becomes negative, while the coefficient of the cross effect variable is positive. Therefore, for younger and smaller firms, the likelihood of collateral is lower in firms with DEFAUL $T_{t+1}=1$ than in firms otherwise. This would be consistent with the use of collateral to signal credit quality by younger and smaller firms, those who are expected to know their credit quality much better than do lenders. As firms get older or larger, lenders increase the soft information about the borrower, and the use of collateral is explained by observed risk [see Jiménez, Salas and Saurina (2006a) for further evidence on this issue].

16. Since the effect of credit market competition on loan characteristics in the world of adverse selection and moral hazard affects mainly younger and smaller firms, where information asymmetry between banks and firms is specially high, the model of collateral has been estimated including HERFINDAHL $x$ Ln AGE and HERFINDAHL $x$ Ln ASSETS, one at a time, as additional explanatory variables, to allow for differences in the effect of market competition on the use of collateral according to the age and size of the firm. The combined coefficient of the HERFINDAHL variable in each case is $(-0.047+0.014 \mathrm{Ln}$ AGE) and $(-0.207+0.026$ Ln ASSETS), respectively (all coefficients statistically significant at $1 \%)$. All remaining coefficients of the model are practically unchanged. The hypothesis is confirmed: market concentration affects the use of collateral more significantly among smaller and younger borrowers than among larger or older ones. 
The coefficient of the proximity variable (-Ln DISTANCE) is now (-0.031+0.017 Ln AGE), and all estimated coefficients are statistically significant. The negative estimated coefficient of the distance variable, in Table III, indicates that for the sample mean of Ln AGE, organizational proximity between lender and borrower increases the likelihood of collateral for loans. The result from Table IV indicates that the effect of proximity on the likelihood of collateral is positive for firms of age over 7 years $\left(e^{0.031 / 0.017}\right)$ and negative for firms less than 7 years old. This evidence is consistent with H2.a, which says that proximity positively affects the likelihood of collateral when the loan is granted to more transparent firms (and age is correlated with transparency). ${ }^{17}$

In Model 2, the cross effect variable is distance times size of the borrower. As predicted, the sign of the cross effect variable is negative, while the estimated coefficient for the DISTANCE variable changes to positive. Therefore, the coefficient of the proximity variable is now $(-0.047+0.007 \mathrm{Ln}$ ASSETS). Again, the two coefficients are statistically significant. For the average size of borrowers, proximity increases the likelihood of collateral (Table III), but the effect of organizational proximity on the likelihood of collateral is positive for larger borrowers (those with assets above 812.5 thousand euros) and negative for smaller ones, as the hypothesis predicts, when differences in size imply differences in informational advantage by closer lenders $(\mathrm{H} 2 . \mathrm{a})$.

When the differences in information between local and distant lenders are captured by the variable duration, the estimated coefficient of duration as a function of distance is (-0.046-0.011 LnDISTANCE). Now, proximity implies higher a likelihood of collateral as duration increases, which is contrary to what was initially predicted (H2.b). Since this result does not support the lender-based theory of collateral, it deserves additional attention. One possible explanation for this contradictory result is that local lenders use their information advantage to delay borrowers, and take more time to reduce the collateral requirements of those borrowers observed to be of high quality. Another plausible explanation is that, as indicated above, distant lenders begin their lending relationship with highly transparent borrowers, and therefore learn quite quickly about their true credit quality. Local lenders, on the other hand, begin the relationship with more opaque borrowers and learning about their credit quality takes place more slowly.

The last column of Table IV shows the estimated coefficient of market concentration, HERFINDAHL, as a function of duration of the borrower-lender relationship, $(-0.032+0.011$ Ln DURATION). ${ }^{18}$ The coefficient of market concentration decreases in absolute value with duration of the relationship. This confirms that, as the outside opportunities of the borrower are reduced (fewer banks in the market), the likelihood of collateral for the loan is also lower, but the effect of the reduction is marginally lower for those loans to borrowers where the information advantage of the lender is higher, that is to say, borrowers who have longer relationships with the lender. This result supports H2.c and Proposition 6 of Inderst and Mueller (2007).

\footnotetext{
17. The estimation of Model 1 can also be formulated in terms of the effect on the likelihood of collateral of an increase in the age of the borrower, for loans granted by local banks, and for loans granted by distant banks. The relevant estimated coefficient is now that of LnAGE, (0.126-0.017 Ln DISTANCE). For a loan granted by a local bank (i.e. Ln DISTANCE=0) the marginal increase in the likelihood of collateral, if age of the borrower increases $1 \%$, is $6.8 \%$, while for a loan at the sample average distance of $354 \mathrm{Km}$ the marginal increase is $3.0 \%$, a full $56.1 \%$ lower. So, an increase in the age of the borrower implies a higher increase in the likelihood of the use of collateral for loans granted by local lenders than for loans granted by distant lenders, consistent with the theory.

18. The coefficient of HERFINDAHL is negative for values of duration lower than 29 years, a value outside the range of sample values of the variable duration.
} 
The lender-based theory of collateral predicts an increase over time in the use of collateral for loans by local lenders whenever advances in availability, transmission and analysis of data increase the efficiency of transactional lending for distant lenders. To see if such increases occurred in our data, the basic model on the determinants of collateral (Model 3, Table IV) is estimated allowing a different time effect for those loans granted by local lenders, DISTANCE=0. The estimated coefficients of the TIME dummy variables from this model, for loans by local lenders and for loans by distant lenders, are represented in Figure 1. The evolution over time of the likelihood of collateral for loans granted by local lenders, and for loans granted by distant lenders, controlling for the other explanatory variables, proceeds in parallel. We have no evidence that the pattern of collateral use for loans by local lenders departs in an increasing trend from the use of collateral by distant lenders, as Inderst and Mueller (2007) conjecture. ${ }^{19}$

19. The time stability of the pattern of differences in the use of collateral between local and distant lenders also suggests that the internal control problems within geographically expanded banks remain relatively invariable over time, besides technological advances, which contrasts with the results of Berger and De Young (2001). 
Spain has by far the largest per capita bank branch density among European countries. ${ }^{20}$ In the past five years, the number of branches has increased at an annual rate above $4 \%$. Evidence from the US for the same time period indicates that banks have been increasing the use of credit scoring and distant lending technologies in small business lending, so that physical distance in business lending is higher today than it was several years ago. We have no direct data on the use of transactional lending technologies by Spanish banks, nor on the physical distance between the bank branch that processes the loan and the location of the firm that gets the loan, but the geographic expansion of bank branches does not fit well with the expansion of physically distant lending.

The Spanish case suggests focusing on the implications, for the terms of business loans, of organizational distance, that is, the distance between the location of the top decision-making power of the bank (i.e. its headquarters) and the location of the borrower who receives a loan. Organizational diseconomies in lending imply that organizational distance is sufficient to preserve the informational advantage of local lenders, even after a distant bank opens a branch in the local market. Organizational distance becomes close to physical distance, which has been investigated as an important variable for the workings of credit markets. Our paper focuses on the implications of distance for the use of collateral for business loans, drawing on the lender-based theory of collateral [Inderst and Mueller (2007)], which explicitly models collateral decisions as a function of distance between borrowers and lenders.

The paper documents the increase in organizational distance in bank lending in Spain during the period 1992 to 2002. The empirical evidence also shows that the likelihood of collateral for loans is less for loans granted by distant than by local lenders. This supports the explanation of collateral from the lender-based theory, saying that collateral is used by local lenders to profit from their superior information advantage about the credit risk of the borrower, while collateral has no significance for loans granted by distant lenders. It also shows that distant lending, and the use of hard data on the borrower in loan decisions, appear to be close substitutes in explaining the use of collateral for loans. This is consistent with the hypothesis that organizational diseconomies in lending will foster specialization of banks in relational and transactional technologies, depending on their comparative advantage: local banks will use more relational lending, and lend to more opaque and informationally complex firms, while distant banks will specialize in transactional technologies and lend to more transparent borrowers. In this respect, we also find that those firms who begin a relationship with a local lender are smaller and younger than those who begin a relationship with a distant lender.

The results of the tests of predictions from the lender-based theory of collateral are mixed. We find evidence that the age of the firm, which can be considered a proxy of information transparency, increases the likelihood of collateral more rapidly for loans from local lenders than for loans from distant lenders. We also find that increases in the informational advantage of lenders (longer duration of the borrower-lender relationship), reduce the likelihood of collateral at a faster pace in less concentrated credit markets (higher

20. See ECB (2005). 
reservation profit of the borrower) than in more concentrated ones. The two results support the lender-based theory of collateral. But at the same time, we find that longer duration in the borrower-lender relationship lowers the likelihood of collateral at a faster pace for loans from distant lenders than for loans from local lenders. In addition, the use of collateral for loans granted by local lenders shows no trend over time. These last two pieces of evidence do not support the lender-based theory of collateral.

Overall, the evidence from the paper suggests that there exists some segmentation in lending technologies by local and distant banks, and that the informational advantage of the local lender, with respect to the risk of the project to be financed, is relevant in explaining the use of collateral, and, possibly, other terms, for loans granted by local lenders. But local lenders are also likely to be affected by borrowers' private information, which creates problems of adverse selection and moral hazard. This could explain why credit market concentration is especially relevant in explaining differences in the likelihood of collateral for loans to smaller and younger firms, i.e. those for whom information asymmetry is expected to be more pronounced (see footnote 16).

One open question is the future of the Spanish banking industry, with larger and more time-consuming networks of branches. High branch density increases customer services and helps banks to increase volume of activity and profits. However, a branch close to the potential borrower does not seem to affect the informational difference between local and distant banks, so the organizational distance between the borrower and the bank is determinant of the lending specialization of banks, not the physical distance determined by the location of the branch. The situation may change in the future, as both banks and customers become more effective and efficient, with technological advances facilitating the use of transactional lending technologies. This is beginning to happen with deposits, where Internet banks already have a significant market share of new deposits. The empirical support of the lender-based theory of collateral, provided in this paper, suggests that it is reasonable to expect a more pronounced specialization of banks in the future, with local banks serving opaque and informational complex borrowers, and national banks, with a smaller branch network than they have today, competing with transactional lending technologies suitable for dealing with more transparent borrowers. 
Table I. Evolution of distant lending to firms by Spanish banks. Whole population of loans to firms from CIR database.

December of every year

Percentage of loans granted by banks

Average distance from the headquarter of the bank to the

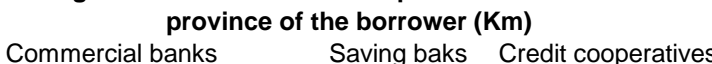

Percentage of bank branches in all provinces except the one with no branches in the province that contains bank headquarters

\begin{tabular}{|c|c|c|c|c|c|c|c|c|c|}
\hline Year & Commercial banks & Saving baks & Credit cooperatives & Commercial banks & Saving baks & Credit cooperatives & Commercial banks & Saving baks & Credit cooperatives \\
\hline 1992 & 3.5 & 8.3 & 9.5 & 372.0 & 236.9 & 72.1 & 77.2 & 39.2 & 11.7 \\
\hline 1993 & 4.2 & 9.0 & 9.1 & 368.4 & 237.5 & 65.0 & 76.5 & 40.7 & 11.9 \\
\hline 1994 & 3.9 & 7.1 & 10.5 & 358.7 & 231.7 & 65.1 & 77.1 & 41.6 & 12.1 \\
\hline 1995 & 3.6 & 6.8 & 9.6 & 362.6 & 235.0 & 64.0 & 77.1 & 42.6 & 12.5 \\
\hline 1996 & 3.5 & 5.8 & 10.5 & 356.5 & 241.5 & 75.0 & 77.1 & 43.7 & 13.3 \\
\hline 1997 & 3.6 & 5.2 & 9.9 & 356.4 & 252.2 & 74.9 & 77.2 & 44.9 & 15.2 \\
\hline 1998 & 3.8 & 4.8 & 8.8 & 363.5 & 247.5 & 72.4 & 77.3 & 46.9 & 16.8 \\
\hline 1999 & 4.2 & 4.7 & 8.0 & 400.3 & 258.0 & 76.5 & 79.2 & 48.6 & 17.8 \\
\hline 2000 & 4.6 & 4.9 & 8.0 & 437.1 & 273.4 & 96.0 & 81.9 & 50.3 & 21.5 \\
\hline 2001 & 4.8 & 4.8 & 7.9 & 438.3 & 286.8 & 99.2 & 81.5 & 51.3 & 23.1 \\
\hline 2002 & 8.2 & 4.8 & 8.1 & 408.0 & 299.9 & 114.3 & 81.7 & 51.9 & 32.4 \\
\hline 2003 & 5.9 & 4.7 & 8.3 & 444.3 & 309.8 & 131.9 & 82.9 & 52.6 & 33.6 \\
\hline 2004 & 5.4 & 4.3 & 8.0 & 437.6 & 309.5 & 146.2 & 82.9 & 53.5 & 34.1 \\
\hline
\end{tabular}


Table II. Descriptive Statistics of the sample variables

\begin{tabular}{|c|c|c|c|c|}
\hline Variables & Mean & S.D. & Minimum & Maximum \\
\hline COLLATERAL $\mathrm{jkt}(1 / 0)$ & 0.31 & 0.46 & 0.00 & 1.00 \\
\hline DISTANCE $_{\mathrm{kt}}$ & 353.84 & 416.94 & 0.00 & $2,684.00$ \\
\hline HERFINDAHL $_{\mathrm{t}}(\%)$ & 7.15 & 2.42 & 3.60 & 20.01 \\
\hline DURATION $_{\mathrm{k}, \mathrm{t}-1}$ & 4.22 & 4.12 & 0.00 & 18.00 \\
\hline NUMBER OF LENDERS $\mathrm{k}, \mathrm{t}-1$ & 4.91 & 4.45 & 0.00 & 23.00 \\
\hline$A G E_{k, t-1}$ & 10.70 & 7.44 & 0.00 & 25.00 \\
\hline DEFAULT $_{\mathrm{k}, \mathrm{t}-1}(1 / 0)$ & 0.02 & 0.13 & 0.00 & 1.00 \\
\hline DEFAULT $_{k, t+1}(1 / 0)$ & 0.03 & 0.17 & 0.00 & 1.00 \\
\hline ASSETS $_{k, t-1}$ & $3,049.58$ & $3,508.54$ & 78.00 & $9,937.00$ \\
\hline 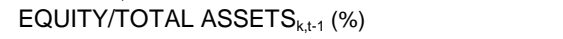 & 26.38 & 18.46 & 2.34 & 74.60 \\
\hline INTERETS INCOME/EBIT $\mathrm{k}_{\mathrm{k}, \mathrm{t}-1}(\%)$ & 48.03 & 48.63 & -68.42 & 148.89 \\
\hline $\mathrm{ROA}_{\mathrm{k}, \mathrm{t}-1}(\%)$ & 7.51 & 6.66 & -5.88 & 24.89 \\
\hline LIQUIDITY RATIO ${ }_{k, t-1}(\%)$ & 102.07 & 59.70 & 21.48 & 280.10 \\
\hline SHORT TERM DEBT/CURRENT ASSETS $\mathrm{k}_{\mathrm{k}, \mathrm{t}-1}(\%)$ & 71.20 & 23.86 & 19.05 & 100.00 \\
\hline SHORT TERM DEBT/TOTAL DEBT ${ }_{k, t-1}(\%)$ & 5.37 & 7.24 & 0.00 & 33.53 \\
\hline SIZE OF THE LOAN ${ }_{\mathrm{jkt}}$ & 402.77 & 959.11 & 6.42 & $6,671.10$ \\
\hline SHORT TERM LOAN jkt $(1 / 0)$ & 0.43 & 0.50 & 0.00 & 1.00 \\
\hline $\mathrm{SHARE}_{\mathrm{kt}}(\%)$ & 7.35 & 6.64 & 0.00 & 41.32 \\
\hline No. Observations & 449,931 & & & \\
\hline No. Firms & 148,869 & & & \\
\hline
\end{tabular}

Mean, standard deviation (S.D.), minimum and maximum values of the variables for the period 19922002. COLLATERALjkt is a dummy variable that takes the value of 1 if the loan $\mathrm{j}$ granted to firm $\mathrm{k}$ in $\mathrm{t}$ has collateral, and 0 otherwise. DISTANCE $E_{k t}$ measures the $\mathrm{Km}$ from the capital of the province where the headquarter of the bank is located, to the capital of the province where the firm receiving the loan is located. HERFINDAHLt is the index of credit market concentration, equal to the sum of banks squared market shares in loans made in each one of the fifty Spanish provinces in year t. DURATION $k, t-1$ is the number of years of lender-borrower relationships before the loan is granted. SHARE $E_{k t}$ is the market share of the bank in business loans in the province where the loan is granted. NUMBER OF LENDERS $S_{k, t-1}$ is the number of banks with which the firm has loans at the time the loan is granted. $A G E_{k, t-1}$ is the number of years since the firm was set up, lagged one year. DEFAUL $T_{k, t-1}$ is a dummy variable with value 1 if the firm $\mathrm{k}$ that gets the loan in $\mathrm{t}$ had a loan in default in $\mathrm{t}-1$, and 0 otherwise. DEFAULT $T_{k, t+1}$ is a dummy variable that takes the value 1 if the firm $k$ does not have a loan in default at the time the loan is granted but defaults in the following year. ASSETS $k_{t,-1}$ is the amount of total assets of the firms. EQUITY/ASSETS $k t,-1$ proxies for the firm's solvency. INTEREST INCOME/EBIT $T_{k, t-1}$ is the coverage of interest expenses by earnings before interest and taxes. $R O A_{k, t-1}$ is the profit over total assets ratio. LIQUIDITY RATIO $k t,-1$ is the ratio between cash and total assets. SHORT TERM DEBT $k$ is firms' debt with a maturity less than one year. SHORT TERM DEBT/CURRENT $\mathrm{kt}_{-1}$ is the inverse of the current ratio. ASSETS SHORT TERM $L O A N_{j k t}$ is a dummy variable that takes one if the loan j has a maturity between one and three years. $S H A R E_{k t}$ is the share of the bank in the province where the loan is granted. All financial ratios and ASSETS $_{k, t-1}$ have been windsorized at percentiles $5 \%$ and $95 \%$. AGE $E_{k, t-1}$ has been windsorized at percentile 95\%. SIZE OF THE LOAN jkt $_{\text {and }}$ ASSETS $k, t-1$ in thousands of euros and in constant prices of 2002. 
Table III. Estimation of the basic model on distance and use of collateral

\begin{tabular}{|c|c|c|c|c|c|c|}
\hline \multirow{3}{*}{$\begin{array}{l}\text { Variable } \\
\\
\text { Dependent Variable } \\
\text { Estimation }\end{array}$} & \multicolumn{2}{|l|}{ Model 1} & \multicolumn{2}{|l|}{ Model 2} & \multicolumn{2}{|l|}{ Model 3} \\
\hline & \multicolumn{2}{|c|}{$\operatorname{COLLATERAL~} \mathrm{jkt}_{(1 / 0)}$} & \multicolumn{2}{|c|}{$\operatorname{COLLATERAL~} \mathrm{jkt}_{(1 / 0)}$} & \multicolumn{2}{|c|}{$\operatorname{COLLATERAL~} \mathrm{jkt}_{(1 / 0)}$} \\
\hline & Logit & & Logit & & Logit & \\
\hline & Coefficient & $S E$ & Coefficient & SE & Coefficient & SE \\
\hline $\log \left(\mathrm{DISTANCE} \mathrm{kt}_{\mathrm{k}}\right)$ & -0.020 & $0.004 * \star *$ & -0.010 & $0.003 * \star *$ & -0.007 & $0.003 * *$ \\
\hline SHARE $_{k t}$ & 0.001 & 0.002 & -- & -- & -- & -- \\
\hline $\log \left(\text { DISTANCE }{ }_{k t}\right)^{*}$ SHARE $_{k t}$ & 0.000 & 0.000 & -- & -- & -- & -- \\
\hline HERFINDAHL $_{\mathrm{t}}$ & -0.013 & $0.005 * \star *$ & -0.017 & $0.005 * \star *$ & -0.019 & $0.005 * * *$ \\
\hline $\log \left(D U R A T I O N_{k, t-1}\right)$ & -- & -- & -- & -- & -0.094 & $0.007 * * *$ \\
\hline Log(NUMBER OF LENDERS $\left.\mathrm{k}_{\mathrm{k}, \mathrm{t}-1}\right)$ & -- & -- & -- & -- & -0.471 & $0.021 * * *$ \\
\hline $\log \left(A G E_{k, t-1}\right)$ & -- & -- & -0.041 & $0.012 * * *$ & 0.056 & $0.012 * * *$ \\
\hline $\operatorname{DEFAULT}_{\mathrm{k}, \mathrm{t}-1}(1 / 0)$ & -- & -- & 0.593 & $0.046 * \star *$ & 0.662 & $0.044 * * *$ \\
\hline $\operatorname{DEFAULT}_{\mathrm{k}, \mathrm{t}+1}(1 / 0)$ & -- & -- & -- & -- & 0.317 & $0.029 * * *$ \\
\hline $\log \left(\right.$ ASSETS $\left._{\mathrm{k}, \mathrm{t}-1}\right)$ & -- & -- & -0.382 & $0.007 * \star \star$ & -0.251 & $0.009 * \star *$ \\
\hline EQUITY/TOTAL ASSETS $\mathrm{k}_{\mathrm{k}, \mathrm{t}-1}$ & -- & -- & -0.008 & $0.000 * \star \star$ & -0.011 & $0.000 * \star *$ \\
\hline INTERETS INCOME/EBIT & -- & -- & 0.000 & 0.000 & 0.001 & $0.000 * \star *$ \\
\hline $\mathrm{ROA}_{k, t-1}$ & -- & -- & -0.004 & 0.001 *** & 0.001 & 0.001 \\
\hline LIQUIDITY RATIO ${ }_{k, t-1}$ & -- & -- & 0.001 & 0.001 * & -0.002 & $0.001 * * *$ \\
\hline SHORT TERM DEBT/CURRENT ASSETS ${ }_{k, t-1}$ & -- & -- & -0.001 & $0.000 * \star *$ & -0.001 & $0.000 * * *$ \\
\hline SHORT TERM DEBT/TOTAL DEBT $T_{k, t-1}$ & -- & -- & -0.006 & $0.000 * * *$ & -0.006 & $0.000 * * *$ \\
\hline Log(SIZE OF THE LOAN $\left.\mathrm{jkt}_{\mathrm{jk}}\right)$ & 0.361 & $0.007 * * *$ & 0.577 & $0.008 * \star \star$ & 0.562 & $0.008 * \star *$ \\
\hline SHORT TERM LOAN $\mathrm{jkt}_{\mathrm{jk}}(1 / 0)$ & -2.494 & $0.014 * \star \star$ & -2.402 & $0.014 * \star \star$ & -2.399 & $0.014 * \star *$ \\
\hline Constant & -0.712 & 0.946 & 2.067 & 0.819 ** & 1.630 & 4.069 \\
\hline Time dummies & yes & & yes & & yes & \\
\hline Reginal dummies & yes & & yes & & yes & \\
\hline Industry dummies & yes & & yes & & yes & \\
\hline Bank dummies & yes & & yes & & yes & \\
\hline No. Observations & 449,931 & & 449,931 & & 449,931 & \\
\hline Pseudo $\mathrm{R}^{2}$ & 0.298 & & 0.323 & & 0.329 & \\
\hline $\log L$ & $-195,547$ & & $-188,605$ & & $-186,908$ & \\
\hline$\chi^{2}$ covariates ( $p$-value) & 0.00 & & 0.00 & & 0.00 & \\
\hline
\end{tabular}

Logistic estimation on the determinants of the use of collateral in loans for the pool of data. Time period 1992-2002. COLLATERAL ikt $_{\text {is }}$ a dummy variable that takes the value of 1 if the loan $\mathrm{j}$ granted to firm $\mathrm{k}$ in $\mathrm{t}$ has collateral and 0 otherwise. DISTANCE $k$ measures the $\mathrm{Km}$ from the capital of the province where the headquarters of the bank is located to the capital of the province where the firm receiving the loan is located. HERFINDAHL $L_{t}$ is the index of credit market concentration, equal to the sum of banks squared market shares in loans made in each one of the fifty Spanish provinces in year t. DURATION $k, t-1$ is the number of years of lender-borrower relationships before the loan is granted. SHARE $E_{k t}$ is the market share of the bank in business loans in the province where the loan is granted. NUMBER OF LENDERS ${ }_{k, t-1}$ is the number of banks with which the firm has loans at the time the loan is granted. $A G E_{k, t-1}$ is the number of years since the firm was set up, lagged one year. DEFAUL $T_{k, t-1}$ is a dummy variable with value 1 if the firm $\mathrm{k}$ that gets the loan in $\mathrm{t}$ had a loan in default in $\mathrm{t}-1$, and 0 otherwise. DEFAUL $T_{k, t+1}$ is a dummy variable that takes the value 1 if the firm $k$ does not have a loan in default at the time the loan is granted but defaults in the following year. ASSETS tt,-1 $_{\text {is }}$ ise amount of total assets of the firms. EQUITY/ASSETS Lt,-1 proxies for the firm's solvency. INTEREST INCOME/EBIT $T_{k, t-1}$ is the coverage of interest expenses by earnings before interest and taxes. $R O A_{k, t-1}$ is the profit over total assets ratio. LIQUIDITY RATIOkt,-1 is the ratio between cash and total assets. SHORT TERM DEBT $T_{k t}$ is firms' debt with a maturity less than one year. SHORT TERM DEBT/CURRENT $\mathrm{kt}_{\text {,-1 }}$ is the inverse of the current ratio. ASSETS SHORT TERM $L O A N_{j k t}$ is a dummy variable that takes one if the loan j has a maturity between one and three years. $S H A R E_{k t}$ is the share of the bank in the province where the loan is granted. 9 time dummies, 49 regional dummies, 10 industry dummies and 194 bank dummies included in all models. Robust standard error (SE) to equal correlation within panels shown. ${ }^{* \star *},{ }^{\star *},{ }^{*}$ mean statistically significant at $1 \%, 5 \%$ and $10 \%$. 
Table IV. Test of predictions from lender-based theory on the effect of distance in the use of collateral for different values of other explanatory variables (cross effects)

\begin{tabular}{|c|c|c|c|c|c|c|c|c|}
\hline Variable & Model 1 & & Model 2 & & Model 3 & & Model 4 & \\
\hline Dependent Variable & COLLATER & $\mathrm{jkt}(1 / 0)$ & COLLATER & $\mathrm{jkt}(1 / 0)$ & COLLATER & $\mathrm{jkt}(1 / 0)$ & COLLATER & $\mathrm{jkt}(1 / 0)$ \\
\hline Estimation & Logit & & Logit & & Logit & & Logit & \\
\hline & Coefficient & $S E$ & Coefficient & SE & Coefficient & $S E$ & Coefficient & $S E$ \\
\hline $\log \left(D_{I S T A N C E}\right)$ & 0.031 & $0.006 * * *$ & 0.047 & $0.010 * * *$ & 0.008 & 0.003 ** & -0.007 & 0.003 ** \\
\hline $\log \left(A G E_{k, t-1}\right) * \log \left(D_{I S T A N C E} E_{k t}\right)$ & -0.017 & $0.002 * \star \star *$ & -- & -- & -- & -- & -- & -- \\
\hline $\log \left(\right.$ ASSETS $\left._{k, t-1}\right) * \log \left(\right.$ DISTANCE $\left._{k t}\right)$ & -- & -- & -0.007 & $0.001 * * *$ & -- & -- & -- & -- \\
\hline $\log \left(D_{U R A T I O N}{ }_{k, t-1}\right) * \log \left(D_{I S T A N C E}{ }_{k t}\right)$ & -- & -- & -- & -- & -0.011 & $0.002 * * *$ & -- & -- \\
\hline HERFINDAHL $_{t}$ & -0.019 & $0.005 * \star *$ & -0.019 & 0.005 *** & -0.019 & $0.005 * \star \star$ & -0.032 & $0.006 * \star \star$ \\
\hline $\log \left(D_{U R A T I O N},{ }_{k,-1}\right)^{*}$ HERFINDAHL $L_{t}$ & -- & -- & -- & -- & -- & -- & 0.011 & $0.002 * * *$ \\
\hline $\log \left(D U R A T I O N_{k, t-1}\right)$ & -0.095 & $0.007 * * \star$ & -0.094 & $0.007^{* * *}$ & -0.046 & $0.011 * * \star$ & -0.170 & $0.020^{* * *}$ \\
\hline $\log \left(N U M B E R\right.$ OF LENDERS $\left.\mathrm{k}_{\mathrm{k}, \mathrm{t}-1}\right)$ & -0.470 & $0.021 * * *$ & -0.469 & $0.021 * * *$ & -0.470 & $0.021 * * \star$ & -0.470 & $0.021 * * *$ \\
\hline $\log \left(A G E_{k, t-1}\right)$ & 0.126 & $0.014 * * *$ & 0.056 & $0.011 * * *$ & 0.053 & $0.012 * \star *$ & 0.055 & $0.012 * \star \star$ \\
\hline $\operatorname{DEFAULT}_{\mathrm{k},-1-1}(1 / 0)$ & 0.662 & $0.044 * * *$ & 0.662 & $0.044 * * *$ & 0.661 & $0.044 * \star \star$ & 0.662 & $0.044 * * *$ \\
\hline DEFAULT $T_{k, t+1}(1 / 0)$ & 0.316 & $0.029 * \star \star$ & 0.316 & $0.029 * * \star$ & 0.316 & $0.029 * \star \star$ & 0.318 & $0.029 * \star \star$ \\
\hline $\log \left(\operatorname{ASSETS}_{k, t-1}\right)$ & -0.252 & $0.009 * * *$ & -0.222 & $0.010 * * *$ & -0.252 & $0.009 * \star \star$ & -0.251 & $0.009 * * \star$ \\
\hline EQUITY/TOTAL ASSETS $\mathrm{K}_{\mathrm{k},-1}$ & -0.011 & $0.000 * * *$ & -0.011 & $0.000 * * *$ & -0.011 & $0.000 * * *$ & -0.011 & $0.000 * * *$ \\
\hline INTERETS INCOME/EBIT & 0.001 & $0.000 * * *$ & 0.001 & $0.000 * * *$ & 0.001 & $0.000 * * *$ & 0.001 & $0.000 * * *$ \\
\hline $\mathrm{ROA}_{k, t-1}$ & 0.001 & 0.001 & 0.001 & 0.001 & 0.001 & 0.001 & 0.001 & 0.001 \\
\hline LIQUIDITY RATIO ${ }_{k, t-1}$ & -0.002 & $0.001 * * *$ & -0.002 & $0.001 * * \star$ & -0.002 & $0.001 * \star *$ & -0.002 & $0.001 * * *$ \\
\hline SHORT TERM DEBT/CURRENT ASSETS $\mathrm{K}_{k, t-1}$ & -0.001 & $0.000 * * *$ & -0.001 & $0.000 * * *$ & -0.001 & $0.000 * * \star$ & -0.001 & $0.000^{* * *}$ \\
\hline SHORT TERM DEBT/TOTAL DEBT ${ }_{k, t-1}$ & -0.006 & $0.000 * * *$ & -0.006 & $0.000 * * *$ & -0.006 & $0.000 * * *$ & -0.006 & $0.000^{* * *}$ \\
\hline Log(SIZE OF THE LOAN $\mathrm{jkt})$ & 0.562 & $0.008 * * *$ & 0.563 & 0.008 *** & 0.562 & $0.008 * * *$ & 0.562 & $0.008^{* \star *}$ \\
\hline SHORT TERM LOAN $\mathrm{jkt}_{\mathrm{jk}}(1 / 0)$ & -2.399 & $0.014 * * *$ & -2.398 & 0.014 *** & -2.399 & 0.014 *** & -2.399 & $0.014 * * \star$ \\
\hline Constant & 1.445 & 0.875 * & 1.403 & 0.872 & 1.518 & 4.141 & 1.689 & 0.873 * \\
\hline Time dummies & yes & & yes & & yes & & yes & \\
\hline Reginal dummies & yes & & yes & & yes & & yes & \\
\hline Industry dummies & yes & & yes & & yes & & yes & \\
\hline Bank dummies & yes & & yes & & yes & & yes & \\
\hline No. Observations & 449,931 & & 449,931 & & 449,931 & & 449,931 & \\
\hline Pseudo $\mathrm{R}^{2}$ & 0.330 & & 0.329 & & 0.329 & & 0.329 & \\
\hline $\log L$ & $-186,869$ & & $-186,884$ & & $-186,887$ & & $-186,894$ & \\
\hline$\chi^{2}$ covariates ( $p$-value) & 0.00 & & 0.00 & & 0.00 & & 0.00 & \\
\hline
\end{tabular}

Logistic estimation on the determinants of the use of collateral in loans for the pool of data.Time period 1992-2002. COLLATERAL $j k$ is a dummy variable that takes the value of 1 if the loan $j$ granted to firm $k$ in $t$ has collateral, and 0 otherwise. DISTANCE $E_{k t}$ measures the $\mathrm{Km}$ form the capital of the province where the headquarter of the bank is located to the capital of the province where the firm receiving the loan is located. HERFINDAHL $t$ is the index of credit market concentration, equal to the sum of banks squared market shares in loans made in each one of the fifty Spanish provinces in year t. DURATION $k_{k, t-1}$ is the number of years of lender-borrower relationships before the loan is granted. SHARE $E_{k t}$ is the market share of the bank in business loans in the province where the loan is granted. NUMBER OF LENDERS ${ }_{k, t-1}$ is the number of banks with which the firm has loans at the time the loan is granted. $A G E_{k, t-1}$ is the number of years since the firm was set up, lagged one year. DEFAUL $T_{k, t-1}$ is a dummy variable with value 1 if the firm $\mathrm{k}$ that gets the loan in $\mathrm{t}$ had a loan in default in $\mathrm{t}-1$, and 0 otherwise. $D E F A U L T_{k, t+1}$ is a dummy variable that takes the value 1 if the firm $\mathrm{k}$ does not have a loan in default at the time the loan is granted but defaults in the following year. ASSETS $k_{t,-1}$ is the amount of total asets of the firms. EQUITY/ASSETS $\mathrm{ktt},-1$ proxies for the firm's solvency. INTEREST INCOME/EBIT $T_{k, t-1}$ is the coverage of interest expenses by earnings before interest and taxes. $R O A_{k, t-1}$ is the profit over total assets ratio. LIQUIDITY RATIO $k_{t,-1}$ is the ratio between cash and total assets. SHORT TERM DEBT $T_{k t}$ is firms' debt with a maturity less than one year. SHORT TERM DEBT/CURRENT kt,-1 $_{1}$ is the inverse of the current ratio. ASSETS SHORT TERM $L O A N_{\text {ikt }}$ is a dummy variable that takes one if the loan $\mathrm{j}$ has a maturity between one and three years. $S H A R E_{k t}$ is the share of the bank in the province where the loan is granted. 9 time dummies, 49 regional dummies, 10 industry dummies and 194 bank dummies included in all models. Robust standard error (SE) to equal correlation within panels shown. ${ }^{\star \star \star},{ }^{* \star},{ }^{*}$ mean statistically significant at $1 \%, 5 \%$ and $10 \%$. 
Figure 1. Time effects on the likelihood of collateral for local and organizational distant lenders after controlling for the rest of explanatory variables.

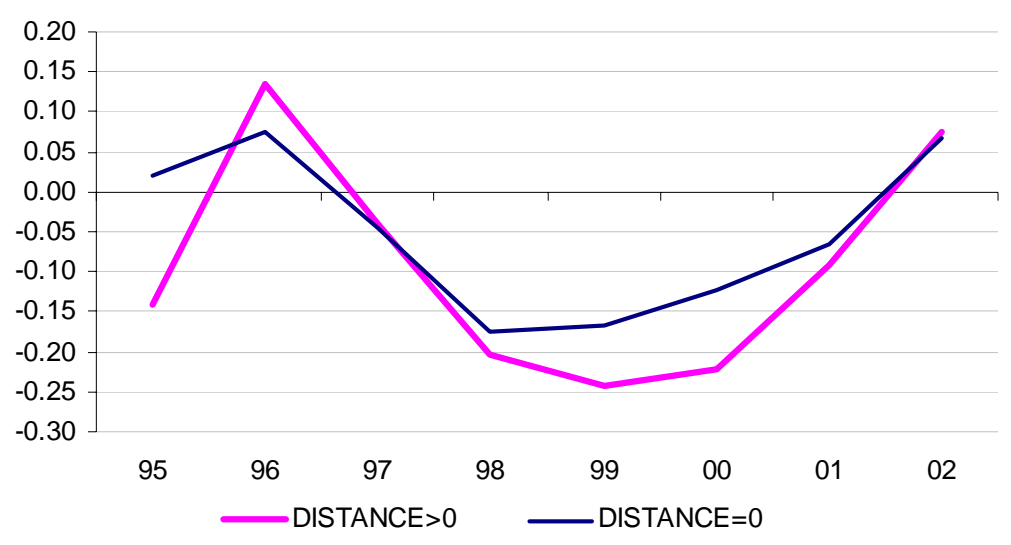




\section{REFERENCES}

AGARWAL, S., and R. HAUSWALD (2007). Distance and informaton asymmetries in lending, mimeo.

AGHION, P., and J. TIROLE (1997). "Formal and real authority in organizations", Journal of Political Economy, 105, pp. 1-22.

ALESSANDRINI, P., A. PRESBITERO and A. ZAZZARO (2006). Banks, distances and fianncing constraints for firms, mimeo.

ALMAZAN, A. (2002). "A model of competition in banking: bank capital vs. expertise", Journal of Financial Intermediation, 11, pp. 87-121.

BERGER, A. N. (2006). "Potential Competitive Effects of Basel II on Banks in SME Credit Markets in the United States", Journal of Financial Sevices Research, 29, pp. 5-36.

BERGER, A. N., and G. F. UDELL (1990). "Collateral, loan quality, and bank risk", Journal of Monetary Economics, 25, pp. $21-24$

— (1995). "Relationship lending and lines of credit in small firm finance", Journal of Business, 68, pp. 351-382.

- (2002). "Small business credit availability and relationship lending: the importance of bank organization structure", Economic Journal, 112, pp. 32-53.

BERGER, A. N., and R. DEYOUNG (2001). "The effects of geographic expansion on bank efficiency", Journal of Financial Services Research, 19, pp. 163-184.

- (2006). "Technological progress and the geographic expansion of the banking industry", Journal of Money, Credit and Banking, 38, pp. 1483-1514

BERGER, A., N. MILLER, M. PETERSEN, R. RAJAN and J. STEIN (2005). "Does function follow organizational form? Evidence from the lending practice of large and small banks", Journal of Financial Economics, 76, pp. 237-269.

BERNANKE, B. S., M. GERTLER and S. GILCHRIST (1999). "The financial accelerator in a quantitative business cycle framework", in J. Taylor and M. Woodford (Eds.), Handbook of Macroeconomics, Vol. 1, Chapter 21, North-Holland, Amsterdam, pp. 1341-1393

BESANKO, D., and A. V. THAKOR (1987a). "Collateral and rationing: sorting equilibria in monopolistic and competitive credit markets", International Economic Review, 28, pp. 671-689.

— (1987b). "Competitive equilibria in the credit market under asymmetric information", Journal of Economic Theory, 42 pp. 167-182.

BESTER, H. (1985). "Screening vs. rationing in credit markets with imperfect information", American Economic Review, 75, pp. 850-855.

BOOT, A. W. A. (2000). "Relationship banking: what do we know?", Journal of Financial Intermediation, 9, pp. 7-25.

BOOT, A. W. A, and A. V. THAKOR (1994). "Moral hazard and secured lending in an infinitely repeated credit market game", International Economic Review, 35, pp. 899-992.

BOOT, A. W. A., A. V. THAKOR and G. F. UDELL (1991). "Secured lending and default risk: equilibrium analysis, policy implications and empirical results", The Economic Journal, 101, pp. 458-472.

BRICKLEY, J., J. LINCK and W. SMITH Jr. (2003). "Boundaries of the firm: Evidence from the banking industry", Journal of Financial Economics, 70, pp. 351-383.

CARLING, K., and S. LUNDBERG (2002). "Asymmetric information and distance: an empirical assessment of geographical credit rationing", Journal of Economics and Business, 57, pp. 39-59.

CHAN, Y. S., and G. KANATAS (1985). "Asymmetric valuation and the role of collateral in loan agreements", Journal of Money, Credit and Banking, 17, pp. 85-95.

CHAN, Y. S., and A. V. THAKOR (1987). "Collateral and Competitive Equilibria with Moral Hazard and Private Information", Journal of Finance, American Finance Association, 42 (2), pp. 345-63.

CHIAPPORI, P. A., D. PEREZ CASTILLO and T. VERDIER (1995). "Spatial competition in the banking system: Localization, cross-subsidies, and the regulation of deposit rates", European Economic Review, 39, pp. 889-918.

DEGRYSE, H., and P. VAN CAYSEELE (2000). "Relationship lending within a bank-based system: evidence from European small business data", Journal of Financial Intermediation, 9, pp. 90-109.

DEGRYSE, H., and S. ONGENA (2005). "Distance, lending relationships and competition", Journal of Finance, 60, pp. 231-266.

DELL'ARICCIA, G., and R. MARQUEZ (2004). "Information and Bank Credit Allocation", Journal of Financial Economics, 72,1 , pp. 185-214.

DEYOUNG, R., W., C. HUNTER and G. F. UDELL (2004). "The past, present, and probable future for community banks", Journal of Financial Services Research, 25, pp. 85-133.

DEYOUNG, R., D. GLENNON and P. NIGRO (2006). Borrower-lender distance, credit scoring and the performance of small business loans, FDIC Center for Financial Research, WP 2006-04.

ECB (2005). EU banking structures, November.

HARHOF, D., and R. KÖRTING (1998). "Lending relationships in Germany-empirical evidence from survey data", Journal of Banking and Finance, 22, pp. 1317-1353.

HARRIS, M., and A. RAVIV (2005). "Allocation of decision making authority", Review of Finance, 9, pp. 353-383.

HAUSWALD, R., and R. MARQUEZ (2006). "Competition and strategic information acquisition in credit markets", The Review of Financial Studies, 19, pp. 967-1000.

INDERST, R., and H. M. MUELLER (2007). "A lender-based theory of collateral", Journal of Financial Economics, vol. 84 No. 3, pp. 826-859.

JIMÉNEZ, G., and J. SAURINA (2004). "Collateral, type of lender and relationship lending as determinant of credit risk", Journal of Banking and Finance, 28, pp. 2191-2212. 
JIMÉNEZ, G., V. SALAS and J. SAURINA (2006a). "Determinants of collateral", Journal of Financial Economics, 81, pp. 251-281.

- (2006b). Credit market competition, collateral and firms' finance, Working Paper No. 0612, Banco de España.

LEETH, J. D., and J. A. SCOTT (1989). "The incidence of secured debt: evidence from the small business community", Journal of Financial and Quantitative Analysis, 24, pp. 379-394.

MESTER, L. J. (1997). "What's the point of credit scoring?", Federal Reserve Bank of Philadelphia Business Review, September/October, pp. 3-16.

PETERSEN, M. A., and R. G. RAJAN (1995). "The effect of credit market competition on lending relationships", Quarterly Journal of Economics, 110, pp. 407-444.

- (2002). "Does distance still matter? The information revolution in small business lending", Journal of Finance, 57, pp. 2533-2570.

RAJAN, R. G. (1992). "Insiders and outsiders: the choice between informed and arm's-length debt", The Journal of Finance, 47, pp. 1367-1399.

SHARPE, S. A. (1990). Asymmetric information, bank lending, and implicit contracts: a stylised model of customer relationships", The Journal of Finance, 45, pp. 1069-1087.

STEIN, J. C. (2002). "Information Production and Capital Allocation: Decentralized vs. Hierarchical Firms", Journal of Finance, 57, pp. 1891-1921.

UDELL, G. F. (1989). "Loan quality, commercial loan review and loan officer contracting", Journal of Banking and Finance, 13, pp. 367-382

WILLIAMSON, O. E. (1967). "Hierarchical control and optimal firm size", Journal of Political Economy, vol. 75. No. 2, pp. 123-138. 


\section{BANCO DE ESPAÑA PUBLICATIONS}

\section{WORKING PAPERS ${ }^{1}$}

0701 PRAVEEN KUJAL AND JUAN RUIZ: Cost effectiveness of R\&D and strategic trade policy.

0702 MARÍA J. NIETO AND LARRY D. WALL: Preconditions for a successful implementation of supervisors' prompt corrective action: Is there a case for a banking standard in the EU?

0703 PHILIP VERMEULEN, DANIEL DIAS, MAARTEN DOSSCHE, ERWAN GAUTIER, IGNACIO HERNANDO, ROBERTO SABBATINI AND HARALD STAHL: Price setting in the euro area: Some stylised facts from individual producer price data.

0704 ROBERTO BLANCO AND FERNANDO RESTOY: Have real interest rates really fallen that much in Spain?

0705 OLYMPIA BOVER AND JUAN F. JIMENO: House prices and employment reallocation: International evidence.

0706 ENRIQUE ALBEROLA AND JOSÉ M. ${ }^{a}$ SERENA: Global financial integration, monetary policy and reserve accumulation. Assessing the limits in emerging economies.

0707 ÁNGEL LEÓN, JAVIER MENCÍA AND ENRIQUE SENTANA: Parametric properties of semi-nonparametric distributions, with applications to option valuation.

0708 ENRIQUE ALBEROLA AND DANIEL NAVIA: Equilibrium exchange rates in the new EU members: external imbalances vs. real convergence.

0709 GABRIEL JIMÉNEZ AND JAVIER MENCÍA: Modelling the distribution of credit losses with observable and latent factors.

0710 JAVIER ANDRÉS, RAFAEL DOMÉNECH AND ANTONIO FATÁS: The stabilizing role of government size.

0711 ALFREDO MARTÍN-OLIVER, VICENTE SALAS-FUMÁS AND JESÚS SAURINA: Measurement of capital stock and input services of Spanish banks.

0712 JESÚS SAURINA AND CARLOS TRUCHARTE: An assessment of Basel II procyclicality in mortgage portfolios.

0713 JOSÉ MANUEL CAMPA AND IGNACIO HERNANDO: The reaction by industry insiders to M\&As in the European financial industry.

0714 MARIO IZQUIERDO, JUAN F. JIMENO AND JUAN A. ROJAS: On the aggregate effects of immigration in Spain.

0715 FABIO CANOVA AND LUCA SALA: Back to square one: identification issues in DSGE models.

0716 FERNANDO NIETO: The determinants of household credit in Spain.

0717 EVA ORTEGA, PABLO BURRIEL, JOSÉ LUIS FERNÁNDEZ, EVA FERRAZ AND SAMUEL HURTADO: Update of the quarterly model of the Bank of Spain. (The Spanish original of this publication has the same number.)

0718 JAVIER ANDRÉS AND FERNANDO RESTOY: Macroeconomic modelling in EMU: how relevant is the change in regime?

0719 FABIO CANOVA, DAVID LÓPEZ-SALIDO AND CLAUDIO MICHELACCI: The labor market effects of technology shocks.

0720 JUAN M. RUIZ AND JOSEP M. VILARRUBIA: The wise use of dummies in gravity models: Export potentials in the Euromed region.

0721 CLAUDIA CANALS, XAVIER GABAIX, JOSEP M. VILARRUBIA AND DAVID WEINSTEIN: Trade patterns, trade balances and idiosyncratic shocks.

0722 MARTÍN VALLCORBA AND JAVIER DELGADO: Determinantes de la morosidad bancaria en una economía dolarizada. El caso uruguayo.

0723 ANTÓN NÁKOV AND ANDREA PESCATORI: Inflation-output gap trade-off with a dominant oil supplier.

0724 JUAN AYUSO, JUAN F. JIMENO AND ERNESTO VILLANUEVA: The effects of the introduction of tax incentives on retirement savings.

0725 DONATO MASCIANDARO, MARÍA J. NIETO AND HENRIEITE PRAST: Financial governance of banking supervision.

0726 LUIS GUTIÉRREZ DE ROZAS: Testing for competition in the Spanish banking industry: The Panzar-Rosse approach revisited.

0727 LUCÍA CUADRO SÁEZ, MARCEL FRATZSCHER AND CHRISTIAN THIMANN: The transmission of emerging market shocks to global equity markets.

0728 AGUSTÍN MARAVALL AND ANA DEL RÍO: Temporal aggregation, systematic sampling, and the Hodrick-Prescott filter.

0729 LUIS J. ÁLVAREZ: What do micro price data tell us on the validity of the New Keynesian Phillips Curve?

0730 ALFREDO MARTÍN-OLIVER AND VICENTE SALAS-FUMÁS: How do intangible assets create economic value? An application to banks.

1. Previously published Working Papers are listed in the Banco de España publications catalogue. 
0731 REBECA JIMÉNEZ-RODRÍGUEZ: The industrial impact of oil price shocks: Evidence from the industries of six OECD countries.

0732 PILAR CUADRADO, AITOR LACUESTA, JOSÉ MARÍA MARTíNEZ AND EDUARDO PÉREZ: El futuro de la tasa de actividad española: un enfoque generacional.

0733 PALOMA ACEVEDO, ENRIQUE ALBEROLA AND CARMEN BROTO: Local debt expansion... vulnerability reduction? An assessment for six crises-prone countries.

0734 PEDRO ALBARRÁN, RAQUEL CARRASCO AND MAITE MARTíNEZ-GRANADO: Inequality for wage earners and self-employed: Evidence from panel data.

0735 ANTÓN NÁKOV AND ANDREA PESCATORI: Oil and the Great Moderation.

0736 MICHIEL VAN LEUVENSTEIJN, JACOB A. BIKKER, ADRIAN VAN RIXTEL AND CHRISTOFFER KOKSØRENSEN: A new approach to measuring competition in the loan markets of the euro area.

0737 MARIO GARCÍA-FERREIRA AND ERNESTO VILLANUEVA: Employment risk and household formation: Evidence from differences in firing costs.

0738 LAURA HOSPIDO: Modelling heterogeneity and dynamics in the volatility of individual wages.

0739 PALOMA LÓPEZ-GARCÍA, SERGIO PUENTE AND ÁNGEL LUIS GÓMEZ: Firm productivity dynamics in Spain.

0740 ALFREDO MARTÍN-OLIVER AND VICENTE SALAS-FUMÁS: The output and profit contribution of information technology and advertising investments in banks.

0741 ÓSCAR ARCE: Price determinacy under non-Ricardian fiscal strategies.

0801 ENRIQUE BENITO: Size, growth and bank dynamics.

0802 RICARDO GIMENO AND JOSÉ MANUEL MARQUÉS: Uncertainty and the price of risk in a nominal convergence process.

0803 ISABEL ARGIMÓN AND PABLO HERNÁNDEZ DE COS: Los determinantes de los saldos presupuestarios de las Comunidades Autónomas.

0804 OLYMPIA BOVER: Wealth inequality and household structure: US vs. Spain.

0805 JAVIER ANDRÉS, J. DAVID LÓPEZ-SALIDO AND EDWARD NELSON: Money and the natural rate of interest: structural estimates for the United States and the euro area.

0806 CARLOS THOMAS: Search frictions, real rigidities and inflation dynamics.

0807 MAXIMO CAMACHO AND GABRIEL PEREZ-QUIROS: Introducing the EURO-STING: Short Term INdicator of Euro Area Growth.

0808 RUBÉN SEGURA-CAYUELA AND JOSEP M. VILARRUBIA: The effect of foreign service on trade volumes and trade partners.

0809 AITOR ERCE: A structural model of sovereign debt issuance: assessing the role of financial factors.

0810 ALICIA GARCÍA-HERRERO AND JUAN M. RUIZ: Do trade and financial linkages foster business cycle synchronization in a small economy?

0811 RUBÉN SEGURA-CAYUELA AND JOSEP M. VILARRUBIA: Uncertainty and entry into export markets.

0812 CARMEN BROTO AND ESTHER RUIZ: Testing for conditional heteroscedasticity in the components of inflation.

0813 JUAN J. DOLADO, MARCEL JANSEN AND JUAN F. JIMENO: On the job search in a model with heterogeneous jobs and workers.

0814 SAMUEL BENTOLILA, JUAN J. DOLADO AND JUAN F. JIMENO: Does immigration affect the Phillips curve? Some evidence for Spain.

0815 ÓSCAR J. ARCE AND J. DAVID LÓPEZ-SALIDO: Housing bubbles.

0816 GABRIEL JIMÉNEZ, VICENTE SALAS-FUMÁS AND JESÚS SAURINA: Organizational distance and use of collateral for business loans.

\begin{tabular}{|r|c|}
\hline & Unidad de Publicaciones \\
BANCODEESPAÑ & Alcalá, 522; 28027 Madrid \\
Eurosistema & Telephone +34 91 338 6363. Fax +34 913386488 \\
& e-mail: publicaciones@bde.es \\
www.bde.es
\end{tabular}

